Roualt, Marie, 1851. Mémoire sur le terrain paléozoïque des environs de Rennes. Bull. Soc. géol. France, Ser. 2e, viii, 358-396.

1855. Notice sur quelques espèces de fossiles du terrain dévonien du nord du département de la Manche. Bull. Soc. géol. France, Ser. $2^{\mathrm{e}}$, xii, 1040-5.

SAlter, A. E., 1899. On the occurrence of Pebbles of Schorl-rock from the South-West of England in the Drift of Southern and Eastern England. Quart. Journ. Geol. Soc., lv, 220-3.

1864. Note on the Fossils from the Budleigh Salterton Pebble-Bed. Quart. Journ. Geol. Soc., xx, 286-302.

Shrubsole, O. H., 1903. On the Probable Source of some of the Pebbles of the Triassic Pebble-beds of South Devon and of the Midland Counties. Quart. Journ. Geol. Soc., lix, 311-331.

Stanley, S. S., 1896. The Origin of Gravel Beds, illustrated in some Local Drifts. Proc. Warwickshire Nat. and Archaeol. Field Club, 15-19.

Tromelin, G. Le G., 1876. Étude de la Fauna du Gres silurien de May, Jurques, Campandre, Mont-Robert, etc. (Calvados) avec des Observations sur divers Fossiles paleozoiques de l'Ouest de la France. Bull. Soc. Linn. de Normandie, Ser. $3^{\mathrm{e}}$, i, 5-80.

Ussher, W. A. E., 1879. On the Triassic Rocks of Normandy and their Environments. Quart. Journ. Geol. Soc., xxxv, 245-267.

Verneuil, P. E. DE, 1847. Note sur le parallélisme des roches des dépôts paléozoïques de l'Amerique Septentrionale avec ceux de l'Europe, suivie d'un tableau des espèces fossiles communes aux deux continents, avec 1'indication des étages où elles se rencontrent, et terminée par un examen critique de chacune de ces espèces. Bull. Soc. géol. France, Ser. $2^{\mathrm{e}}$, iv, 646-710.

WeIss, E., 1885. Zur Flora der ältesten Schichten des Harzes. Jahrb. K. Preuss. geol. Landesanst. und Bergakad. (for 1884), 148-180, pls. v-vii.

\title{
ANNOUNCEMENT
}

\section{Edinburgh Geological Society}

\section{Clough Memorial Research Fund}

This fund was instituted in 1935 for the purpose of encouraging geological research in Scotland and the North of England. The North of England is defined as comprising the counties of Northumberland, Durham, Cumberland, Westmorland, and Yorkshire. Under the terms of administration of the fund, a sum of approximately $£ 30$ is available annually.

Applications for grants are invited for the period 1st April, 1946, to 31st March, 1947. These applications should state : (1) the nature of the research to be undertaken; (2) the amount of grant desired; (3) the specific purpose for which the grant will be used, e.g. travelling expenses, maintenance in field, excavation of critical sections, etc. ; (4) whether any other grant-in-aid has been obtained or applied for.

Applications must be in the hands of the Secretary, Clough Memorial Research Fund Committee, Edinburgh Geological Society, Synod Hall, Castle Terrace, Edinburgh, not later than 1st March, 1946. 